\title{
Adult-specific over-expression of the Drosophila genes magu and hebe increases life span and modulates late-age female fecundity
}

\author{
Yishi Li $\cdot$ John Tower
}

Received: 3 September 2008 / Accepted: 24 October 2008 / Published online: 15 November 2008

(C) The Author(s) 2008. This article is published with open access at Springerlink.com

\begin{abstract}
During Drosophila aging mortality rate increases exponentially and progeny production per animal declines dramatically, correlating with decreased number and division of somatic and germ-line stem cells in the gonads. To search for genes that might promote both longevity and fecundity, a $\mathrm{P}$ element transposon $(P d L)$, containing an outwardly directed, doxycycline-inducible promoter was used to generate conditional mutations. Mutant females were screened for increased fecundity at late ages in the presence of doxycycline. Two genes were identified, named hebe (CG1623) and magu (CG2264), that when over-expressed in adult flies could increase life span by $\sim 5-30 \%$ in both sexes and increase female fecundity at late ages. Transcripts for magu are enriched in the Drosophila stem cell niche region, and magu encodes a protein related to the human SMOC2 regulator of angiogenesis. While moderate over-expression of magu in adult females increased fecundity at late ages, high-level over-expression of magu was maternal-effect lethal. The data demonstrate that adult-specific over-expression of hebe and magu can increase life span and modulate female fecundity, and provide further evidence against obligatory trade-offs between reproduction and longevity.
\end{abstract}

Keywords Aging $\cdot \mathrm{P}$ element $\cdot$ Oogenesis $\cdot$ Stem cell . Trade-off

Communicated by T. Nyström.

Y. Li $\cdot$ J. Tower $(\bowtie)$

Molecular and Computational Biology Program,

Department of Biological Sciences,

University of Southern California, Los Angeles,

CA 90089-2910, USA

e-mail: jtower@usc.edu

URL: http://towerlab.USC.edu/

\section{Introduction}

Among the defining characteristics of aging across species are an exponential increase in mortality rate and reduced fecundity (progeny production), and it is possible that these conserved features of aging might have a common underlying mechanism (Hekimi 2006). Drosophila is a well-developed model system for the study of both aging and reproduction (Partridge et al. 2005; Partridge and Tower 2008), thereby facilitating the search for regulators that might be shared between these processes. For example the insulin/IGF1-like signaling (IIS) pathway negatively regulates life span in Drosophila (Clancy et al. 2001; Tatar et al. 2001) and other species (Kenyon 2005; Selman et al. 2008), and positively regulates Drosophila oogenesis in response to dietary protein (Drummond-Barbosa and Spradling 2001; Hsu et al. 2008). Drosophila gametogenesis involves the continued division of both germ line and somatic stem cell populations located at the anterior tip of the gonads (Fuller and Spradling 2007). The germ-line stem cells give rise to the oocyte and sperm, while the somatic stem cells produce short-lived tissues that provide nourishment and support to the developing germ-line cells. In response to a protein-rich diet, the Drosophila nervous system produces insulin-like peptides (DILPs) that activate the IIS pathway in ovarian stem cells to increase their rate of division (LaFever and Drummond-Barbosa 2005). Gametogenesis and reproduction in Drosophila responds to additional hormonal and circadian inputs, and is stimulated by mating (Howlader and Sharma 2006; Toivonen and Partridge 2008).

Decreased gamete production during Drosophila aging corresponds with decreased number and division of stem cells in both the ovary (Waskar et al. 2005; Pan et al. 2007; Zhao et al. 2008) and testes (Wallenfang et al. 2006; Boyle 
et al. 2007). Both intrinsic changes (within the stem cells) and extrinsic changes (systemic signals) are implicated in the decline in stem cell function during aging, including alterations in the stem cell niche, which is the specialized microenvironment that confers upon stem cells the ability to self-renew (Morrison and Spradling 2008).

The relationship between reproduction and life span is not entirely clear. In C. elegans signals from both germ-line and somatic tissues in the gonad can act through the IIS pathway to affect the life span of the animal (Yamawaki et al. 2008). In Drosophila it has been reported that ablation of germ-line stem cells does not affect life span (Barnes et al. 2006), however, more recently it is reported that ablation of germ-line stem cells increases life span and alters IIS (Flatt et al. 2008). While trade-offs between reproduction and life span have often been reported in Drosophila and other organisms, it has also been reported that under certain circumstances these traits can be uncoupled (Partridge et al. 2005; Barnes et al. 2006; Flatt and Kawecki 2007).

Conditional transgene over-expression systems, where transgene expression is induced by a heat pulse, or by feeding flies a drug such as DOX (Bieschke et al. 1998) or RU486/Mifepristone (Ford et al. 2007), provide a powerful method to test genes for effects on life span and reproduction. With the conditional systems, the control and experimental (gene over-expressing) groups have identical genetic backgrounds, and therefore the effects of the transgene can be identified without confounding effects of genetic background (Sun and Tower 1999; Tower 2000; Curtis et al. 2007; Giannakou et al. 2008; Min et al. 2008). Placing a conditional (DOX-dependent) promoter facing outward from a $\mathrm{P}$ element transposon (the " $P d L$ " $\mathrm{P}$ element) allows for the efficient screening of Drosophila genes for overexpression phenotypes, including effects on life span (Landis et al. 2001; Landis et al. 2003) and oogenesis (Khokhar et al. 2008). In particular, the dominant and conditional nature of the $P d L$ gene-over-expression mutations allows screening for effects on reproduction at the level of the individual (F1) mutant female fly. Here we report the use of $P d L$ mutagenesis to search for genes that are positive regulators of both female fecundity and life span.

\section{Materials and methods}

\section{Drosophila strains and culture}

Drosophila strains and culture conditions are as previously described (Ford et al. 2007). Experiments were preformed at $25^{\circ} \mathrm{C}$ using a standard cornmeal/agar media (Ren et al. 2007). To cause conditional gene expression using the Teton system, flies were cultured on media containing doxycy- cline and ampicillin each at a final concentration of $64 \mu \mathrm{g} /$ $\mathrm{ml}$ ("+DOX”). For the control groups ("-DOX”), flies were cultured on media containing ampicillin only.

Generation of wild type female fecundity curve

A cohort of 40 Oregon- $\mathrm{R}$ virgin female flies was collected over a period of $48 \mathrm{~h}$ and designated as 1 day old. They were separated into 10 vials with 4 virgins in each vial together with 4 young Oregon-R males and kept in $25^{\circ} \mathrm{C}$. Flies in each vial were transferred to fresh food vials every other day and the number of dead flies was recorded, and the old vials were kept at $25^{\circ} \mathrm{C}$ for subsequent progeny counts. Every month 4 young Oregon-R males were added to each vial to replenish the old males, and the experiment was performed until all the females were dead. The pupae number in each vial was counted 10 days after each transfer. For each vial, the number of pupae was divided by the number of females in that specific period to yield progeny per female. The average pupae number per female \pm SEM was calculated across the 10 replicate vials. A preliminary version of this data was presented in a review article (Waskar et al. 2005), and the data is included here with further statistical analysis for comparison purposes.

\section{Genetic screen for new $P d L$ mutations}

Virgin flies from strain PdL45Cl were crossed to males from strain delta2-3. The male progeny containing both the $P d L 45 C 1$ insertion and delta2-3 were selected by their phenotypic markers and crossed to virgins of strain rtTA(3)E2. The virgin progeny flies containing a new $P d L$ insertion and $\operatorname{rtTA}(3) E 2$ have the ability to over-express the gene immediately downstream of the $P d L$ insertion, and $\sim 8,000$ of these mutants were generated and analyzed. Each individual mutant female was combined with three young Oregon-R male flies and cultured on -DOX food for the first 35 days of their life span. During this process the flies were transferred to fresh food vials every 2 days. At the end of the 35 day period, the flies were then cultured on - DOX food for 4 days ("time period 1"). The flies were then cultured on +DOX food for 8 days to allow any gene overexpression and phenotypes to become maximal. The flies were then cultured on +DOX food for an additional 4 days ("time period 2"). During these steps the flies were always transferred to fresh food vials every other day. Pupal number was counted in vials 10 days after transfer. Because control flies showed significant decrease in fecundity between time period 1 and time period 2, any mutants that did not show a significant decrease in fecundity in this interval were considered potential positives and were further characterized. The site of insertion of $P d L$ was determined using inverse PCR, sequencing, and comparison 
between the $P d L$ flanking sequence and fly genomic DNA databases using NCBI-BLAST, as previously described (Landis et al. 2001).

\section{Creation of constructs and transgenic flies}

The full-length cDNA clones for the magu and hebe genes were ordered from BACPAC (http://bacpac.chori.org/) (BACPAC Resources Center at Children's Hospital Oakland Research Institute in Oakland, California). The cDNA was amplified from its clone vector POT1. For magu the forward primer was 5'-TGACGAATTCGAACTGCT AAG-3'; for hebe the forward primer was 5'-TTCAAAGG CAGACAGACATGG-3'; the reverse primer anneals to the POT1 vector and was 5'-CGTTAGAACGCGGCTACAA TT- ${ }^{\prime}$. The amplified cDNAs were ligated into the USC1.0 vector that contains the mini-white $e^{+}$marker gene (Allikian et al. 2002) to create $\mathrm{P}\{$ magu $\}$ and $\mathrm{P}\{$ hebe $\}$ transformation constructs, respectively. Multiple independent transgenic strains were generated for each construct by embryo microinjection using standard protocols (Rubin and Spradling 1982) and the $y$-ac- $w$ recipient strain (Patton et al. 1992).

\section{Northern blot}

Northern blot assay was performed essentially as previously described (Landis et al. 2003). Briefly, strains bearing a $P d L$ insertion or a transgene insertion were crossed with rtTA(3)E2 flies. The male and female progeny were collected separately and cultured on + DOX and - DOX food for 10 days. Total RNA was extracted from 30 flies of each group using Trizol kit (Invitrogen), resolved on 2\% agarose gels, and then transferred to Genescreen membrane (Dupont/NEN). Restriction fragments from the cDNA clones of the magu and hebe genes were radiolabelled and used as gene-specific probes. Ribosomal protein 49 (Rp49) probe was used as loading control. Transcript size was determined by comparison with $1 \mathrm{~Kb}$ RNA ladder (Gibco$\mathrm{BRL}$ ) according to the manufacturer's instructions.

Female fecundity assays

Female fecundity was assayed in a longitudinal protocol analogous to the screening procedure described above, except that multiple flies (four vials each containing four females) were used to provide replication and statistical inference (Fig. 1c). Female fecundity was also assayed in a parallel protocol, which involved four replicate vials, each containing four females and four wild-type males, for each of + DOX and - DOX conditions. Flies were transferred to fresh vials every other day. For the experiments with DOX administered beginning on day 1 (Fig. 5), the progeny numbers (pupae) were recorded in the old vials in the time inter- vals between day 10 and 20 ("time period 1") and between day 30 and 40 ("time period 2"). For the experiments with DOX administered beginning on day 40 (Fig. 6), the progeny numbers (pupae) were recorded in the old vials in the time intervals between day 35 and 39 ("time period 1") and between day 45 and 49 ("time period 2"). The average progeny per female for each time interval was calculated, and + DOX values were compared to - DOX values using unpaired, two-sided $t$ tests. For certain experiments, the final concentration of DOX in the food was diluted 1:5 and $1: 25$ as indicated.

\section{Egg hatch assay}

The fraction of eggs hatching was assayed for the two strains in which magu cDNA over-expression caused decreased fecundity, $\mathrm{P}\{$ magu $\} 102$ and $\mathrm{P}\{$ magu $\} 103$. These strains were crossed to driver rtTA(3)E2 to generate progeny containing both constructs, while controls were generated by crossing $\operatorname{rtTA}(3) \mathrm{E} 2$ to $w[1118]$ to generate progeny containing only $\mathrm{rtTA}(3) \mathrm{E} 2$, which are referred to in the text as "Control w[1118]". Progeny females were collected and at 4 days of age they were mated to Oregon $\mathrm{R}$ wild type males, and flies were cultured on food with and without DOX for 10 days, with transfer to fresh food every other day. Forty females plus ten males were then placed in an inverted bottle with a charcoal plate at the bottom overnight ( $12 \mathrm{~h}$ total). The dark charcoal plates facilitate visualization of eggs and hatched eggs. The bottles contained a cotton-stoppered hole for air exchange. Three replicate bottles were used for each condition. The charcoal plates were removed and scored for total number of eggs laid, and after an additional $12 \mathrm{~h}$ the plates were scored for the number of hatched eggs. Average and SD were calculated using the triplicate plates, and for each genotype the - DOX value was compared to the + DOX value using unpaired, two-sided $t$ tests. We note that the flies lay significantly fewer eggs in the over-night charcoal plate collection assay than during day-long collections of eggs in culture vials.

Life span assays

Each transgenic strain was crossed to driver rtTA(3)E2 to generate progeny containing both constructs, while controls were generated by crossing rtTA(3)E2 to w[1118] to generate progeny containing only rtTA(3)E2, which are referred to in the text as "Control w[1118]", and by crossing $\operatorname{rtTA}(3) \mathrm{E} 2$ to Oregon $\mathrm{R}$ to generate progeny containing only rtTA(3)E2, which are referred to in the text as "Control Or-R". Life span assays were performed at $25^{\circ} \mathrm{C}$ with passage to fresh food vials every other day as previously described (Ford et al. 2007). Each cohort consisted of $\sim 125$ 


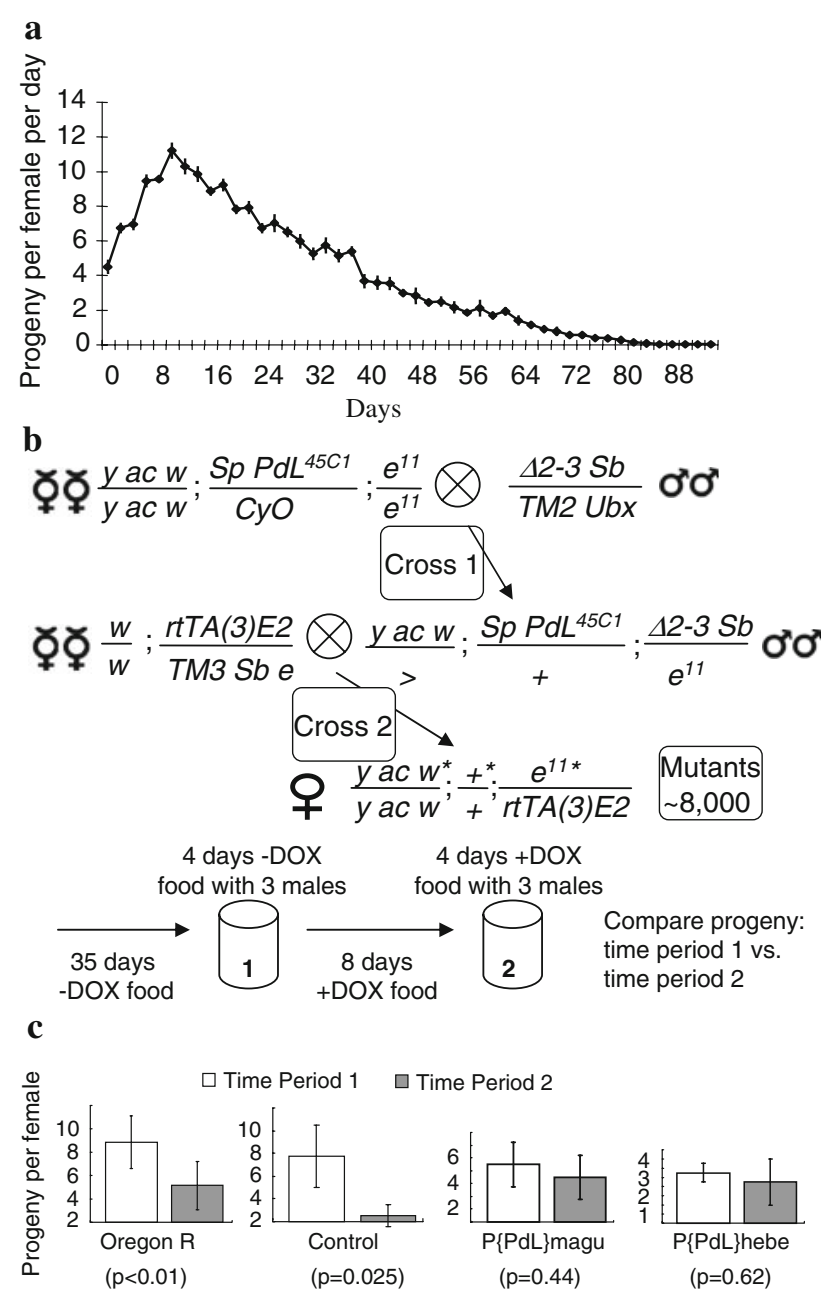

Fig. 1 Isolation of hebe and magu gene over-expression mutations. a Female fecundity of Oregon-R wild-type flies. Data are plotted as progeny per female per day versus age in days; error bars indicate SEM. b Genetic screen strategy. The starting $P d L \mathrm{P}$ element insertion on the second chromosome $\left(P d L^{45 C l}\right)$ was crossed to the delta2-3 transposase source (cross 1). Male progeny containing both $P d L^{45 C l}$ and delta2-3 were crossed to third-chromosome balancer strain virgins (cross 2). Female progeny bearing a new insertion of the $P d L$ element on either the first, second or third chromosome (indicated by asterisk; $\sim 8,000$ total) were identified by presence of the mini-white ${ }^{+}$marker gene in $P d L$. Each female was mated to three Oregon-R males and cultured for 35 days on - DOX food. Progeny production was then assayed for the next 4 days ("time period 1") with addition of fresh, young Oregon-R males. The flies were then transferred to +DOX food for 8 days to induce any gene over-expression. Progeny production was then assayed for the next 4 days on +DOX food ("time period 2"). For females where the progeny count in time period 2 was equal to or greater than time period 1, the new $P d L$ insertion was recovered from the progeny from time period 1. c Progeny per female per day during time period 1 and time period 2 for longitudinal assays of replicate flies of Oregon-R wild-type, Control (Oregon $R \quad x \quad r t T A(3) E 2)$, $\mathrm{P}\{\mathrm{PdL}\}$ magu and $\mathrm{P}\{\mathrm{PdL}\}$ hebe strains, as indicated

flies at $\sim 25$ flies per vial, and median life spans of +DOX samples were compared to -DOX controls using log-rank tests.
Protein motif analyses

The protein motif search was performed using four different databases: InterPro (http://www.ebi.ac.uk/interpro/), GenomeNet (http://www.genome.jp/), ScanProsite (http:// expasy.org/cgi-bin/scanprosite), and Sanger Institute Pfam (http://pfam.sanger.ac.uk/).

\section{Results}

Screening for gene over-expression mutations that increase late-age female fecundity using $P d L$

In Drosophila, female fecundity peaks in the first 2 weeks, and then declines dramatically with advancing age (Fig. 1) (Waskar et al. 2005; Zhao et al. 2008). To identify genes that might positively regulate both fecundity and life span, $P d L$ mutagenesis was employed to create gene over-expression mutations. The $P d L$ P element contains an outwardly directed, DOX-regulated promoter that will cause overexpression of genes located downstream of the $3^{\prime}$ end of the element. The rtTA(3)E2 transgenic strain contains a construct in which the powerful, tissue-general promoter from the cytoplasmic actin gene (actin5C) drives expression of the artificial transcription factor rtTA. The rtTA transcription factor is activated upon interaction with DOX, and then binds to specific sites (Tet-operator sites) in the $P d L$ promoter, thereby mediating DOX-inducible transcription. In this way feeding DOX to a fly containing both $P d L$ and rtTA(3)E2 can cause robust over-expression of a gene located $3^{\prime}$ to $P d L$ in all of the somatic tissues of the fly.

Strain $P d L[45 \mathrm{C} 1]$ contains an insert of $P d L$ on the second chromosome, which is also marked with the dominant mutation Sternopleural ( $S p$ ). Virgins of this strain were crossed to males from strain delta2-3, which expresses $\mathrm{P}$ element transposase ("Cross 1"; Fig. 1b). The male progeny containing both the $P d L[45 \mathrm{C} 1]$ insertion and delta2-3 were selected by their phenotypic markers. In these males the transposase will cause transposition of $P d L$ to new sites in the genome in the germ line cells, and therefore these males are called "dysgenic". The dysgenic males were crossed to virgins of strain rtTA(3)E2 ("Cross 2"; Fig. 1b) to produce mutant female progeny bearing a new insertion of $P d L$ on either the first, second or third chromosomes (indicated by asterisk), as well as the $\operatorname{rtTA}(3) \mathrm{E} 2$ driver. The new insertions were identified by the presence of the mini-white $e^{+}$ marker gene in $P d L$, and the absence of the $S p$ mutation marking the chromosome bearing the starting $P d L$ insertion. Approximately 8,000 of these mutant females were generated and analyzed. The mutant females were combined with Oregon-R male flies and cultured on -DOX food for the first 35 days of their life span. During this process 
the flies were transferred to fresh food vials every 2 days. At the end of the 35 day period, the female flies were then individually cultured in the presence of 3 Oregon- $R$ wild type males on -DOX food for 4 days ("time period 1"), to allow measure of progeny production. The flies were then cultured on + DOX food for 8 days to allow any gene overexpression and phenotypes to become maximal. The flies were then cultured on + DOX food for an additional 4 days ("time period 2") to again allow measure of progeny production. During these steps the flies were always transferred to fresh food vials every other day. The number of progeny produced by the mutant females (pupae) was counted in each vial 10 days after transfer. Because control flies showed significant decrease in fecundity between time period 1 and time period 2 (Fig. 1c), any mutant females that did not show a significant decrease in fecundity in this interval were considered potential positives and were further characterized. Eight mutant females were identified where there was little or no decrease in fecundity between time period 1 and time period 2. These eight promising new $P d L$ insertions were balanced, and re-tested for fecundity effects using replicate females (Fig. 1c), and also tested for effects on life span (described below). Two mutants consistently gave positive results and were further pursued, hereafter referred to as $\mathrm{P}\{\mathrm{PdL}\}$ magu and $\mathrm{P}\{\mathrm{PdL}\}$ hebe, named for immortal deities from Chinese and Greek mythology, respectively.

\section{Conditional over-expression of hebe and magu cDNAs}

Inverse PCR was used to clone the genomic DNA immediately adjacent to the $3^{\prime}$ end of the $P d L$ insertions in lines $\mathrm{P}\{\mathrm{PdL}\}$ hebe and $\mathrm{P}\{\mathrm{PdL}\}$ magu. Comparison of the flanking sequences to the GenBank database revealed that both inserts are located immediately upstream of the transcriptional start site for the respective genes (Fig. 2a): $\mathrm{P}\{\mathrm{PdL}\}$ hebe is inserted $6,721 \mathrm{bp}$ upstream of the translational start site (ATG) for gene CG1623 (hebe), while $\mathrm{P}\{\mathrm{PdL}\}$ magu was located in the first intron of gene CG2264 (magu), 4,646 bp upstream of the translation start site. In both cases the $3^{\prime}$ end of $P d L$ was oriented towards the open reading frame, suggesting that DOX would cause over-expression of functional, full-length proteins. Fulllength cDNA clones for both hebe and magu were obtained from a commercial source (BACPAC Resources Center at Children's Hospital Oakland Research Institute). Northern blot analysis confirmed the DOX-dependent over-expression of both the hebe and magu genes in the $\mathrm{P}\{\mathrm{PdL}\}$ hebe and $\mathrm{P}\{\mathrm{PdL}\}$ magu mutant strains, in both male and female adult flies (Fig. 3a, b).

To confirm the phenotypic effects of hebe and magu over-expression, the corresponding cDNAs were cloned into the USC1.0 vector, to allow for DOX-dependent over-
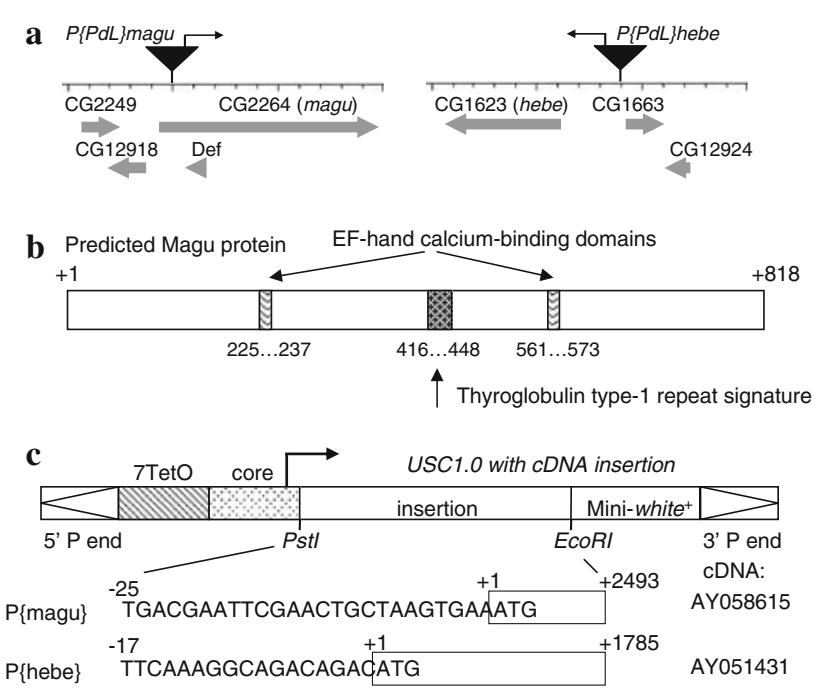

Fig. 2 Diagram of magu and hebe loci and transgenic constructs. a The location and orientation of the P $\{\mathrm{PdL}\}$ magu and $\mathrm{P}\{\mathrm{PdL}\}$ hebe insertions relative to adjacent genes. b Protein motifs in the predicted Magu protein. c The over-expression constructs $\mathrm{P}\{$ magu $\}$ and $\mathrm{P}\{$ hebe $\}$, generated by cloning of the indicated cDNA clones into the USC1.0 vector

expression in an otherwise wild-type genetic background (Fig. 2c). Multiple independent lines were generated for each over-expression construct (Table 1), and Northern blot analysis confirmed DOX-dependent over-expression of the transgenes in both male and female adult flies (Fig. 3c, d). The magu gene was also found to be expressed throughout the body of wild type flies (Fig. 3e).

Ubiquitous over-expression of hebe and magu in adults increases male and female life span

The $\operatorname{rtTA}(3) E 2$ ubiquitous driver was used to cause DOXdependent over-expression of hebe and magu genes in adult flies. The original $\mathrm{P}\{\mathrm{PdL}\}$ hebe and $\mathrm{P}\{\mathrm{PdL}\}$ magu insertions were assayed, along with multiple independent cDNA overexpression construct insertions for each gene, in replicate experiments. Representative survival curves are presented (Fig. 4), and the statistical analysis is presented for each strain and replicate experiment (Table 2). Control genotypes were generated by crossing the Oregon-R wild-type and w[1118] injection strains to the $\operatorname{rtTA}(3) \mathrm{E} 2$ ubiquitous driver strain, to generate progeny expressing rtTA but containing no target transgene. In these controls DOX treatment caused no significant change in life span of either male or female flies (Fig. 4a, b; Table 2). The P\{PdL $\}$ hebe mutation yielded a $31 \%$ increase in median life in males and a $24 \%$ increase in mean life span in males. In females the $\mathrm{P}\{\mathrm{PdL}\}$ hebe mutation yielded a $2.2 \%$ increase in median life span and a $11 \%$ increase in mean life span. The three independent hebe cDNA over-expression strains yielded increases in median life span in males ranging from 
Fig. 3 Northern analyses. (a-d) DOX-dependent gene overexpression. The indicated strains were crossed to the $\operatorname{rtTA}(3) \mathrm{E} 2$ ubiquitous driver and male and female progeny containing both constructs were cultured as adults for 1 week, in the presence and absence of DOX, as indicated. Total RNA was isolated from 30 flies of each type, and $4 \mu \mathrm{g}$ (" $1 \mathrm{X}$ ") and $8 \mu \mathrm{g}$ (" $2 \mathrm{X}$ ") of each sample was fractionated and blotted, as indicated. Blots were hybridized sequentially with probes specific for genes magu, hebe, and Rp49 loading control, as indicated. a The original $\mathrm{P}\{\mathrm{PdL}\}$ magu insertion. b The original $\mathrm{P}\{\mathrm{PdL}\}$ hebe insertion. c Two independent transgenic insertions of the magu cDNA over-expression construct, $\mathrm{P}\{$ magu $\} 103$ and $\mathrm{P}\{$ magu $\} 67-1$, as indicated. $\mathbf{d}$ Two independent transgenic insertions of the hebe cDNA over-expression construct, $\mathrm{P}\{$ hebe $\} \mathrm{DX} 2$ and $\mathrm{P}\{$ hebe $\} \mathrm{DX} 1$, as indicated. e Expression of magu in dissected tissues from Oregon R wild-type flies, as indicated a

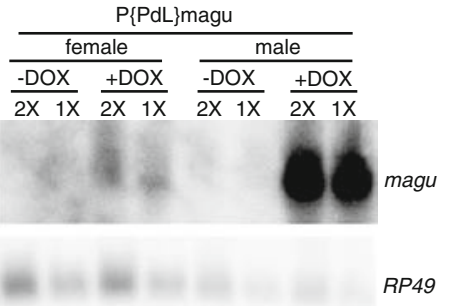

b $\frac{P\{P d L\} \text { hebe }}{\frac{\text { female }}{\frac{-D O X}{2 X 1 X} \frac{+D O X}{2 X 1 X}} \frac{\text { male }}{\frac{-D O X}{2 X 1 X}} \frac{+D O X}{2 X 1 X}}$ hebe cos RP49

c
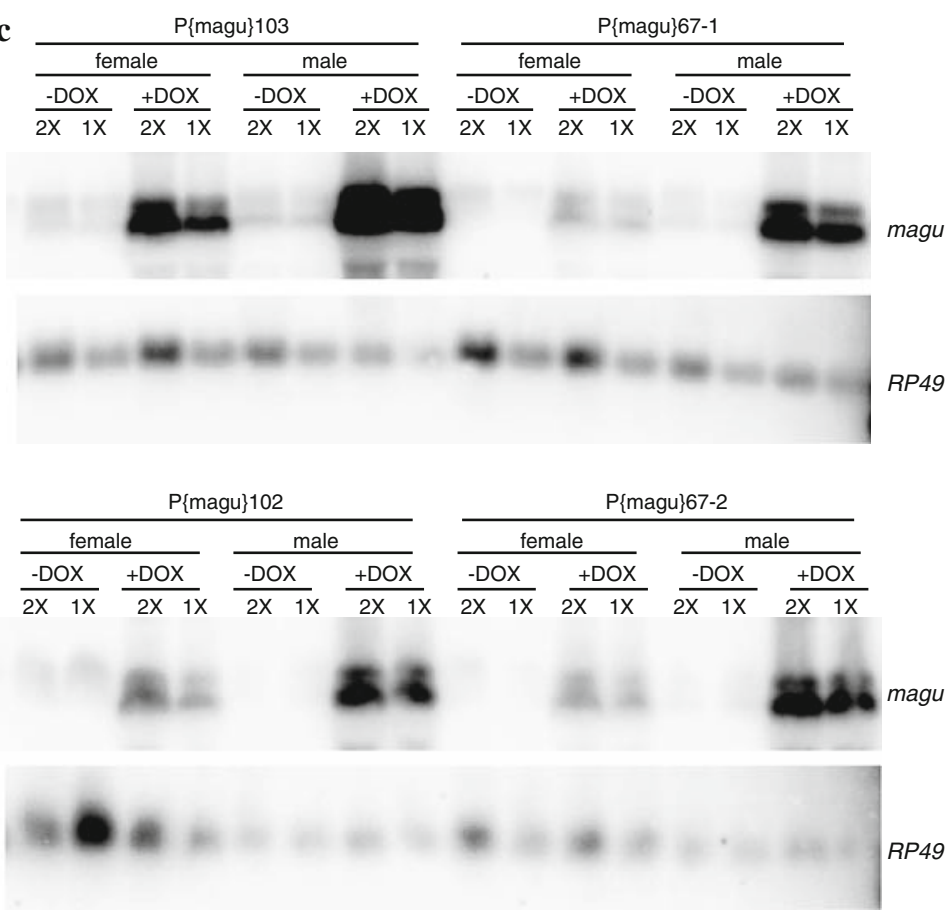

d

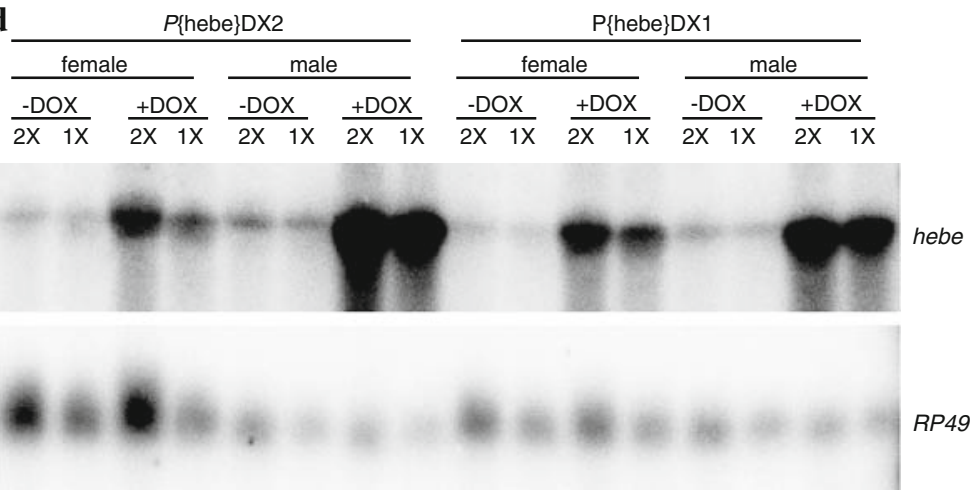

e Oregon-R Female

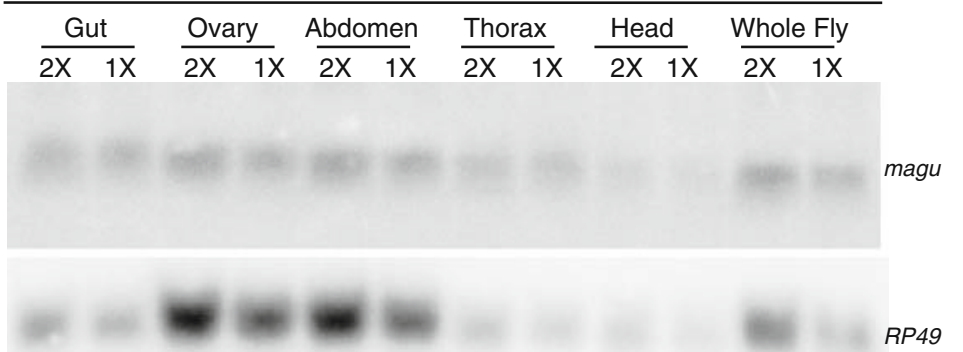


Table 1 Transgenic strains

\begin{tabular}{lll}
\hline Construct & Line name & Chromosome \\
\hline PdL & magu & 2nd \\
& hebe & 2nd \\
P\{magu $\}$ & 39 & 2nd \\
& 102 & $3 \mathrm{rd}$ \\
& 103 & $2 \mathrm{nd}$ \\
& $67-1$ & $3 \mathrm{rd}$ \\
P\{hebe $\}$ & $67-2$ & $3 \mathrm{rd}$ \\
& DX1 & 2nd \\
& DX2 & 2nd \\
& AX & 3rd \\
\hline
\end{tabular}

7 to $26 \%$, while increases in females ranged from 6 to $23 \%$. Similar but somewhat more variable results were obtained upon ubiquitous over-expression of magu. The $\mathrm{P}\{\mathrm{PdL}\}$ magu mutation yielded $9.3 \%$ increase in median life in males and a $5.3 \%$ increase in mean life span in males. In females the $\mathrm{P}\{\mathrm{PdL}\}$ magu mutation yielded a $2.2 \%$ increase in median life span and a $5.3 \%$ increase in mean life span. Five independent magu cDNA over-expression construct insertions were assayed in the first experiment, and three of these $(\mathrm{P}\{$ magu $\} 102, \mathrm{P}\{$ magu $\} 67-1$, and $\mathrm{P}\{$ magu $\} 39)$ yielded increases in median life span in both males and females ranging from 2 to $18 \%$. In contrast line $\mathrm{P}\{$ magu $\} 103$ yielded $14 \%$ increase in median life span in males but no increase in females, while line $\mathrm{P}\{$ magu $\} 67-2$ gave no increase in either sex. In the second experiment with the ubiquitous rtTA(3)E2 driver, the two magu cDNA lines tested ( $\mathrm{P}\{$ magu $\} 102$ and $\mathrm{P}\{$ magu $\} 67-1)$ each gave increases in median life span in both males and females, ranging from 2.6 to $21 \%$. The specific chromosomal site of insertion of $\mathrm{P}$ element constructs can affect expression levels in various tissues, and we hypothesize that this may be why results varied for the five independent magu cDNA strains. However, two of the magu cDNA strains, $\mathrm{P}\{$ magu $\} 102$ and $\mathrm{P}\{$ magu $67-1$, yielded significant increases for both males and females in the replicate experiments. Therefore, we conclude that while life span effects varied considerably across strains and experiments, ubiquitous over-expression of both hebe and magu can increase life span in both male and female adult flies.

Over-expression of hebe and magu preferentially in adult motor-neurons increases female life span

We have recently described a system consisting of three transgenic constructs that allows for tissue-specific, DOXdependent transgene expression that can be modulated over three orders of magnitude (Ford et al. 2007). The D42 driver is a well-characterized GAL4/UAS system driver that yields expression of the yeast GAL4 transcription factor throughout the developing nervous system and preferentially in motorneuron tissue in adult flies (Parkes et al. 1998). The UAS-rtTA ${ }^{\text {m2alt901 }}$ insertion (Stebbins et al. 2001) is a "bridge construct" that is regulated by GAL4 to yield expression of rtTA only in those same tissues. Finally, as discussed above, the Tet-on promoter in $P d L$ (or USC1.0 for the cDNA constructs) will be activated by rtTA only in the presence of DOX. Therefore, the combination of these three constructs yields DOX-inducible expression of transgenes in adult flies, preferentially in motorneuron tissue (Ford et al. 2007).

The control genotype for the motorneuron expression experiments contained the motorneuron driver and the bridge construct, but no target construct, and in these flies there was no significant change in life span in males or females in the replicate experiments (Fig. 4i; Table 3). Two independent hebe cDNA lines were tested, $\mathrm{P}\{$ hebe $\} \mathrm{DX} 2$ and $\mathrm{P}\{$ hebe $\} \mathrm{AX}$, and in the first experiment these lines yielded increases in median life span in females of 22 and $38 \%$, respectively, while no significant effect was obtained in males. Two independent magu cDNA over-expression strains were also tested, $\mathrm{P}\{$ magu $\} 102$ and $\mathrm{P}\{$ magu $\} 67-1$, and these lines yielded increases in median life span in females of 28 and $28 \%$, respectively, and no significant alteration in life span in males. Therefore, in the first experiment utilizing the D42 motorneuron driver, both hebe and magu over-expression increased life span in female flies but not male flies. In contrast, in the replicate experiment, both the hebe and magu cDNA over-expression constructs yielded increases in median life span in both males and females, ranging from 9 to $37 \%$. In summary, while the life span increases varied considerably across strains and experiments, the conditional over-expression of hebe and magu in adult motorneuron tissue consistently increased life span in females, with less consistent increases observed in males.

Ubiquitous over-expression of hebe and magu in adult females modulates fecundity

To confirm effects of hebe and magu gene over-expression on adult female fecundity, the original $P d L$ mutations, $\mathrm{P}\{\mathrm{PdL}\}$ hebe and $\mathrm{P}\{\mathrm{PdL}\}$ magu, as well as two independent cDNA expression lines for each gene were ubiquitously over-expressed in adult females, using varying amounts of DOX to vary the degree of over-expression. Adult females were cultured on -DOX media and media supplemented with varying concentrations of DOX, beginning at day 1 of age and continuing throughout the adult life span. Female fecundity was assayed at two time periods: day 10-day 20 (time period 1), and from day 30 to day 40 (time period 2) (Fig. 5). The control genotype contained the $\operatorname{rtTA}(3) \mathrm{E} 2$ driver and no target construct, and in these control flies 
Fig. 4 Life span assays. The indicated strains were crossed to the $\operatorname{rtTA}(3) \mathrm{E} 2$ ubiquitous driver (a-h) or D42 motor-neuron driver $(\mathbf{i}, \mathbf{j})$, and male $(\mathbf{a}, \mathbf{c}, \mathbf{e}, \mathbf{g})$ and female $(\mathbf{b}, \mathbf{d}, \mathbf{f}, \mathbf{h}, \mathbf{i}, \mathbf{j})$ progeny containing both constructs were cultured as adults, in the presence (open diamonds) and absence (solid squares) of DOX, as indicated. a, b Control flies; the progeny of Oregon-R wild-type crossed to rtTA(3)E2 driver. c, $\mathbf{d}$ $\mathrm{P}\{$ magu $\}$ 67-1 cDNA overexpression strain. $\mathbf{e}, \mathbf{f}$ $\mathrm{P}\{$ magu $\} 102$ cDNA overexpression strain. $\mathbf{g}, \mathbf{h}$ $\mathrm{P}\{$ hebe $\} \mathrm{DX} 2$ cDNA overexpression strain. i, $\mathbf{j}$ The D42 motor-neuron driver crossed to $\mathrm{w}$ [1118] control (i) and $\mathrm{P}\{$ magu $\} 102$ cDNA overexpression strain (j). The percent change in median life span + DOX is indicated, along with $p$ value for log-rank test. Statistical data for these strains, additional independent strains, and replicate experiments is summarized in Tables 2 and 3
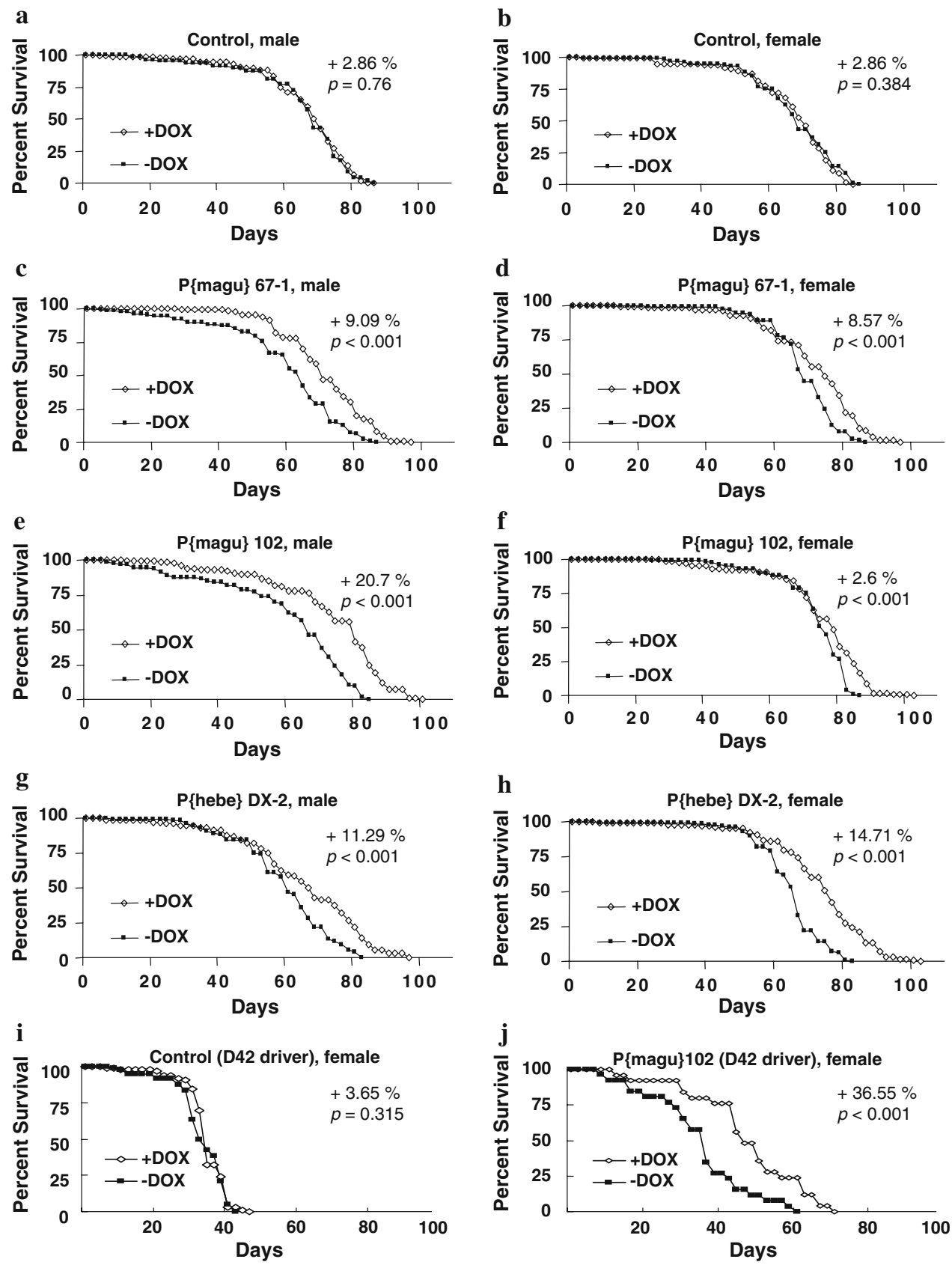

DOX had no significant effect on female fecundity at either time point (Fig. 5a). In contrast the $\mathrm{P}\{\mathrm{PdL}\}$ magu insertion increased female fecundity at late ages (Fig. 5b), consistent with the screening procedure by which it was identified above. The magu cDNA over-expression line $\mathrm{P}\{$ magu $\} 67-$ 1 also increased female fecundity at late ages, however, in this case there was an apparent trade-off with reduced female fecundity at the earlier time point (Fig. 5c). Interestingly the magu cDNA line $\mathrm{P}\{$ magu $\} 102$ caused dosedependent decreases in female fecundity at both time points (Fig. 5d), and similar reductions were obtained with line $\mathrm{P}\{$ magu $\} 103$ (data not shown). The reduced fecundity caused by over-expression of $\mathrm{P}\{$ magu $\} 102$ and $\mathrm{P}\{$ magu $\} 103$ was due primarily to maternal-effect lethality, in that relatively normal quantities of morphologically normal-appearing eggs were laid (Fig. 5h), but the majority of these eggs failed to hatch (Fig. 5i). The maternal-effect lethal phenotype observed with lines $\mathrm{P}\{$ magu $\} 102$ and $\mathrm{P}\{$ magu $\} 103$ may be because these lines yielded higher and perhaps toxic levels of cDNA over-expression in adult females; in contrast the $\mathrm{P}\{\mathrm{PdL}\}$ magu and $\mathrm{P}\{$ magu $\} 67-1$ lines that produced increased female fecundity were associated with more modest increases in magu expression (Fig. 3c). For the original $\mathrm{P}\{\mathrm{PdL}\}$ hebe mutation, the change in late-age female fecundity did not reach statistical significance in this experiment (Fig. 5e). However, the hebe cDNA line 
Table 2 Lifespan assay using ubiquitous driver rtTA(3)E2

\begin{tabular}{|c|c|c|c|c|c|c|c|c|}
\hline Strain & DOX & Sex & Median & Mean & SD & $\Delta$ Median $(\%)$ & $\Delta$ Mean $(\%)$ & $p$ value \\
\hline \multicolumn{9}{|l|}{ Experiment 1} \\
\hline w1118 & + & M & 92 & 87.2 & 14.5 & 0 & 0.12 & 0.448 \\
\hline w1118 & - & M & 92 & 87.0 & 14.9 & & & \\
\hline w1118 & + & $\mathrm{F}$ & 76 & 80.1 & 14.2 & 0.00 & 0.21 & 0.672 \\
\hline w1118 & - & $\mathrm{F}$ & 76 & 79.9 & 14.3 & & & \\
\hline Or-R & + & M & 92 & 85.7 & 16.8 & 2.22 & -0.69 & 0.678 \\
\hline Or-R & - & M & 90 & 86.3 & 13.8 & & & \\
\hline Or-R & + & $\mathrm{F}$ & 76 & 78.2 & 13.4 & 0.00 & -2.04 & 0.977 \\
\hline Or-R & - & $\mathrm{F}$ & 76 & 79.9 & 12.3 & & & \\
\hline $\mathrm{P}\{\mathrm{PdL}\} \mathrm{magu}$ & + & M & 94 & 88.1 & 15.8 & 9.30 & 8.59 & $4.50 \mathrm{E}-06$ \\
\hline $\mathrm{P}\{\mathrm{PdL}\}$ magu & - & M & 86 & 81.1 & 15.2 & & & \\
\hline $\mathrm{P}\{\mathrm{PdL}\}$ magu & + & $\mathrm{F}$ & 92 & 90.7 & 8.7 & 2.22 & 5.28 & $4.85 \mathrm{E}-05$ \\
\hline $\mathrm{P}\{\mathrm{PdL}\}$ magu & - & $\mathrm{F}$ & 90 & 86.1 & 9.0 & & & \\
\hline $\mathrm{P}\{\mathrm{PdL}\}$ hebe & + & M & 92 & 88.8 & 15.6 & 31.43 & 24.21 & $9.10 \mathrm{E}-15$ \\
\hline $\mathrm{P}\{\mathrm{PdL}\}$ hebe & - & M & 70 & 71.5 & 18.5 & & & \\
\hline $\mathrm{P}\{\mathrm{PdL}\}$ hebe & + & $\mathrm{F}$ & 92 & 90.7 & 10.9 & 2.22 & 11.25 & $1.02 \mathrm{E}-07$ \\
\hline $\mathrm{P}\{\mathrm{PdL}\}$ hebe & - & $\mathrm{F}$ & 90 & 81.6 & 14.7 & & & \\
\hline $\mathrm{P}\{$ magu $\} 102$ & + & M & 98 & 96.0 & 17.7 & 8.89 & 23.77 & $1.11 \mathrm{E}-16$ \\
\hline $\mathrm{P}\{\mathrm{magu}\} 102$ & - & M & 90 & 77.5 & 22.8 & & & \\
\hline $\mathrm{P}\{\mathrm{magu}\} 102$ & + & $\mathrm{F}$ & 90 & 86.8 & 11.0 & 7.14 & 9.34 & 0.00176 \\
\hline $\mathrm{P}\{$ magu $\} 102$ & - & $\mathrm{F}$ & 84 & 79.4 & 15.9 & & & \\
\hline $\mathrm{P}\{$ magu $\} 103$ & + & M & 96 & 88.2 & 18.1 & 14.29 & 20.13 & $5.47 \mathrm{E}-05$ \\
\hline $\mathrm{P}\{$ magu $\} 103$ & - & M & 84 & 73.4 & 26.9 & & & \\
\hline $\mathrm{P}\{$ magu $\} 103$ & + & $\mathrm{F}$ & 72 & 76.7 & 14.3 & 0.00 & 4.66 & 0.652 \\
\hline $\mathrm{P}\{$ magu $\} 103$ & - & $\mathrm{F}$ & 72 & 73.36 & 19.9 & & & \\
\hline $\mathrm{P}\{$ magu $\} 67-1$ & + & M & 96 & 93.6 & 17.8 & 2.13 & 11.64 & $6.79 \mathrm{E}-07$ \\
\hline $\mathrm{P}\{$ magu $\} 67-1$ & - & M & 94 & 83.8 & 20.7 & & & \\
\hline $\mathrm{P}\{$ magu $\} 67-1$ & + & $\mathrm{F}$ & 90 & 86.9 & 13.1 & 18.42 & 13.85 & $8.91 \mathrm{E}-08$ \\
\hline $\mathrm{P}\{$ magu $\} 67-1$ & - & $\mathrm{F}$ & 76 & 76.3 & 15.4 & & & \\
\hline $\mathrm{P}\{$ magu $\} 67-2$ & + & M & 86 & 84.6 & 15.8 & -4.44 & -3.91 & 0.439 \\
\hline $\mathrm{P}\{$ magu $\} 67-2$ & - & M & 90 & 88.0 & 7.9 & & & \\
\hline $\mathrm{P}\{$ magu $\} 67-2$ & + & $\mathrm{F}$ & 90 & 81.3 & 23.4 & 0.00 & 0.12 & 0.688 \\
\hline $\mathrm{P}\{$ magu $\} 67-2$ & - & $\mathrm{F}$ & 90 & 81.2 & 18.8 & & & \\
\hline $\mathrm{P}\{$ hebe $\} \mathrm{DX} 1$ & + & M & 90 & 83.5 & 21.5 & 7.14 & 9.14 & 0.00028 \\
\hline $\mathrm{P}\{$ hebe $\} \mathrm{DX} 1$ & - & M & 84 & 76.5 & 20.9 & & & \\
\hline $\mathrm{P}\{$ hebe $\} \mathrm{DX} 1$ & + & $\mathrm{F}$ & 72 & 77.8 & 13.6 & 5.88 & 9.16 & 0.000506 \\
\hline $\mathrm{P}\{$ hebe $\} \mathrm{DX} 1$ & - & $\mathrm{F}$ & 68 & 71.2 & 14.8 & & & \\
\hline $\mathrm{P}\{$ hebe $\} \mathrm{DX} 2$ & + & M & 96 & 85.5 & 23.4 & 26.32 & 15.62 & $2.34 \mathrm{E}-10$ \\
\hline $\mathrm{P}\{$ hebe $\} \mathrm{DX} 2$ & - & M & 76 & 74.0 & 21.3 & & & \\
\hline $\mathrm{P}\{$ hebe $\} \mathrm{DX} 2$ & + & $\mathrm{F}$ & 84 & 81.3 & 14.1 & 20.00 & 15.65 & $1.10 \mathrm{E}-09$ \\
\hline $\mathrm{P}\{$ hebe $\} \mathrm{DX} 2$ & - & $\mathrm{F}$ & 70 & 70.3 & 13.5 & & & \\
\hline $\mathrm{P}\{$ hebe $\} \mathrm{AX}$ & + & M & 92 & 88.6 & 15.3 & 21.05 & 12.60 & $3.24 \mathrm{E}-08$ \\
\hline $\mathrm{P}\{$ hebe $\} \mathrm{AX}$ & - & M & 76 & 78.6 & 15.1 & & & \\
\hline $\mathrm{P}\{$ hebe $\} \mathrm{AX}$ & + & $\mathrm{F}$ & 86 & 83.1 & 14.6 & 22.86 & 11.80 & $6.16 \mathrm{E}-08$ \\
\hline $\mathrm{P}\{$ hebe $\} \mathrm{AX}$ & - & $\mathrm{F}$ & 70 & 74.3 & 14.7 & & & \\
\hline $\mathrm{P}\{$ magu $\} 39$ & + & M & 86 & 85.0 & 20.1 & 7.50 & -3.98 & 0.762 \\
\hline $\mathrm{P}\{$ magu $\} 39$ & - & M & 80 & 88.5 & 18.1 & & & \\
\hline $\mathrm{P}\{$ magu $\} 39$ & + & $\mathrm{F}$ & 94 & 88.7 & 16.7 & 4.44 & 0.67 & 0.0405 \\
\hline $\mathrm{P}\{$ magu $\} 39$ & - & $\mathrm{F}$ & 90 & 88.1 & 11.9 & & & \\
\hline
\end{tabular}


Table 2 continued

\begin{tabular}{|c|c|c|c|c|c|c|c|c|}
\hline Strain & DOX & Sex & Median & Mean & SD & $\Delta$ Median $(\%)$ & $\Delta$ Mean $(\%)$ & $p$ value \\
\hline \multicolumn{9}{|l|}{ Experiment 2} \\
\hline w1118 & + & M & 72 & 68.0 & 14.2 & 2.86 & 1.61 & 0.76 \\
\hline w1118 & - & M & 70 & 66.9 & 15.3 & & & \\
\hline w1118 & + & $\mathrm{F}$ & 72 & 68.2 & 14.1 & 2.86 & -0.52 & 0.384 \\
\hline w1118 & - & $\mathrm{F}$ & 70 & 68.6 & 13.7 & & & \\
\hline $\mathrm{P}\{$ magu $\} 102$ & + & M & 82 & 75.3 & 18.1 & 20.59 & 20.72 & $1.06 \mathrm{E}-12$ \\
\hline $\mathrm{P}\{$ magu $\} 102$ & - & M & 68 & 62.4 & 20.0 & & & \\
\hline $\mathrm{P}\{$ magu $\} 102$ & + & $\mathrm{F}$ & 80 & 77.0 & 14.2 & 2.56 & 2.63 & 0.000502 \\
\hline $\mathrm{P}\{$ magu $\} 102$ & - & $\mathrm{F}$ & 78 & 75.0 & 10.7 & & & \\
\hline $\mathrm{P}\{$ magu $\} 67-1$ & + & M & 72 & 72.7 & 12.4 & 9.09 & 18.39 & $1.73 \mathrm{E}-07$ \\
\hline $\mathrm{P}\{$ magu $\} 67-1$ & - & M & 66 & 61.4 & 17.3 & & & \\
\hline $\mathrm{P}\{$ magu $\} 67-1$ & + & $\mathrm{F}$ & 76 & 73.1 & 14.3 & 8.57 & 4.60 & 3.64E-05 \\
\hline $\mathrm{P}\{$ magu $\} 67-1$ & - & $\mathrm{F}$ & 70 & 69.8 & 9.8 & & & \\
\hline $\mathrm{P}\{$ hebe $\} \mathrm{DX}-2$ & + & M & 69 & 66.8 & 18.6 & 11.29 & 9.54 & $2.39 \mathrm{E}-05$ \\
\hline $\mathrm{P}\{$ hebe $\} \mathrm{DX}-2$ & - & M & 62 & 61.0 & 14.0 & & & \\
\hline $\mathrm{P}\{$ hebe $\} \mathrm{DX}-2$ & + & $\mathrm{F}$ & 78 & 75.1 & 14.8 & 14.71 & 14.07 & $4.50 \mathrm{E}-13$ \\
\hline $\mathrm{P}\{$ hebe $\} \mathrm{DX}-2$ & - & $\mathrm{F}$ & 68 & 65.8 & 10.1 & & & \\
\hline $\mathrm{P}\{$ hebe $\} \mathrm{AX}$ & + & M & 70 & 65.7 & 19.7 & 12.90 & 7.04 & $2.09 \mathrm{E}-05$ \\
\hline $\mathrm{P}\{$ hebe $\} \mathrm{AX}$ & - & M & 62 & 61.4 & 13.0 & & & \\
\hline $\mathrm{P}\{$ hebe $\} \mathrm{AX}$ & + & $\mathrm{F}$ & 74 & 72.2 & 13.0 & 8.82 & 8.57 & 4.70E-07 \\
\hline $\mathrm{P}\{$ hebe $\} \mathrm{AX}$ & - & $\mathrm{F}$ & 68 & 66.5 & 11.1 & & & \\
\hline
\end{tabular}

$\mathrm{P}\{$ hebe $\} \mathrm{DX} 2$ did yield increased fecundity at late ages (Fig. 5f), and each hebe over-expression line was associated with decreased fecundity at the earlier time point, demonstrating that hebe over-expression can modulate female fecundity.

To determine if late age fecundity could be increased without a trade-off with earlier age fecundity, the fecundity assay experiment was repeated with DOX administration and gene over-expression initiated only at age 40 days (Fig. 6). Female fecundity was assayed at two time periods: day 35-day 39 (time period 1), and from day 45 to day 49 (time period 2). The control genotypes contained the rtTA(3)E2 driver and no target construct, and in these control flies DOX had no significant effect on female fecundity at either time point (Fig. 6a, b). In contrast, the original $\mathrm{P}\{\mathrm{PdL}\}$ magu insertion and three independent magu cDNA lines, as well as the original $\mathrm{P}\{\mathrm{PdL}\}$ hebe mutation and two independent hebe cDNA lines, all increased female fecundity at late ages at one or more DOX concentrations (Fig. 6c-i). As expected fecundity was not affected at time point 1 for any of the transgenic lines, since time point 1 was prior to drug administration. The late-age administration of drug had no negative effect on female survival (Fig. 6j-1), and in fact for $\mathrm{P}\{\mathrm{PdL}\}$ magu survival was increased. These data demonstrate that over-expression of hebe and magu at late ages could increase female fecundity with no detectable trade-off with early age fecundity or life span.

\section{Discussion}

In this study 8,000 gene-over-expression mutations were generated in Drosophila, and screened for effects on lateage female fecundity. Two genes were identified; hebe and magu, that when over-expressed in adult flies could increase late-age female fecundity and extend life span. These reagents should be useful for the further study of aging mechanisms, and the results provide additional evidence against the existence of an obligatory trade-off between reproduction and longevity.

Because $P d L$ gene over-expression mutations are both conditional (DOX-dependent) and dominant (only one copy of the gene needs be mutated), it means that new mutations do not need to be made homozygous, and phenotypes can be assayed in each mutant (F1) female (Khokhar et al. 2008). In the mutagenesis strategy employed here each mutant $\mathrm{F} 1$ female bearing a new $P d L$ insertion was assayed longitudinally for fecundity phenotype before and after induction of gene over-expression by DOX. In this way the mutations of interest could be recovered from the progeny produced by the female prior to DOX treatment and induction of any phenotypes. However, even with this efficiency only 8,000 females have been screened so far, meaning that only a fraction of the $\sim 14,000$ Drosophila genes have been tested, and therefore it is likely that additional genes remain to be identified that can positively affect both fecundity and longevity. 
Table 3 Life span assay using motor-neuron driver D42

\begin{tabular}{|c|c|c|c|c|c|c|c|c|}
\hline Strain & DOX & Sex & Median & Mean & SD & $\Delta$ Median $(\%)$ & $\Delta$ Mean $(\%)$ & $p$ value \\
\hline \multicolumn{9}{|l|}{ Experiment 1} \\
\hline w1118 & + & M & 38 & 35.8 & 11.1 & 11.76 & 0.00 & 0.809 \\
\hline w1118 & - & M & 34 & 35.8 & 11.1 & & & \\
\hline w1118 & + & $\mathrm{F}$ & 34 & 34.1 & 6.1 & 6.25 & 3.65 & 0.315 \\
\hline w1118 & - & $\mathrm{F}$ & 32 & 32.9 & 7.3 & & & \\
\hline $\mathrm{P}\{$ magu $\} 102$ & + & M & 38 & 37.2 & 14.5 & 11.76 & -0.53 & 0.884 \\
\hline $\mathrm{P}\{$ magu $\} 102$ & - & M & 34 & 37.4 & 13 & & & \\
\hline $\mathrm{P}\{$ magu $\} 102$ & + & $\mathrm{F}$ & 46 & 46.7 & 14.7 & 27.78 & 36.55 & 0.000893 \\
\hline $\mathrm{P}\{$ magu $\} 102$ & - & $\mathrm{F}$ & 36 & 34.2 & 13.2 & & & \\
\hline $\mathrm{P}\{$ magu $\} 67-1$ & + & M & 44 & 41.9 & 15.7 & 0.00 & -3.68 & 0.547 \\
\hline $\mathrm{P}\{$ magu $\} 67-1$ & - & M & 44 & 43.5 & 11.1 & & & \\
\hline $\mathrm{P}\{$ magu $\} 67-1$ & + & $\mathrm{F}$ & 46 & 45.3 & 13.5 & 27.78 & 23.43 & $2.14 \mathrm{E}-06$ \\
\hline $\mathrm{P}\{$ magu $\} 67-1$ & - & $\mathrm{F}$ & 36 & 36.7 & 13.7 & & & \\
\hline $\mathrm{P}\{$ hebe $\} \mathrm{DX} 2$ & + & M & 38 & 39.4 & 12.9 & 11.76 & 10.36 & 0.127 \\
\hline $\mathrm{P}\{$ hebe $\} \mathrm{DX} 2$ & - & M & 34 & 35.7 & 13.9 & & & \\
\hline $\mathrm{P}\{$ hebe $\} \mathrm{DX} 2$ & + & $\mathrm{F}$ & 44 & 42.3 & 13.9 & 22.22 & 17.83 & 0.00121 \\
\hline $\mathrm{P}\{$ hebe $\} \mathrm{DX} 2$ & - & $\mathrm{F}$ & 36 & 35.9 & 10.9 & & & \\
\hline $\mathrm{P}\{$ hebe $\} \mathrm{AX}$ & + & M & 28 & 32.7 & 14.1 & -22.22 & -8.91 & 0.187 \\
\hline $\mathrm{P}\{$ hebe $\} \mathrm{AX}$ & - & M & 36 & 35.9 & 15 & & & \\
\hline $\mathrm{P}\{$ hebe $\} \mathrm{AX}$ & + & $\mathrm{F}$ & 44 & 39.6 & 16 & 37.50 & 24.53 & 0.00887 \\
\hline $\mathrm{P}\{$ hebe $\} \mathrm{AX}$ & - & $\mathrm{F}$ & 32 & 31.8 & 14.4 & & & \\
\hline \multicolumn{9}{|l|}{ Experiment 2} \\
\hline w1118 & + & M & 50 & 48.4 & 10.5 & 0 & -1 & 0.948 \\
\hline w1118 & - & M & 50 & 48.9 & 8.8 & & & \\
\hline w1118 & + & $\mathrm{F}$ & 50 & 51.7 & 7.6 & -3.8 & 5.5 & 0.583 \\
\hline w1118 & - & $\mathrm{F}$ & 52 & 49.0 & 11.5 & & & \\
\hline $\mathrm{P}\{$ magu $\} 102$ & + & M & 52 & 45.9 & 17.6 & 36.8 & 32.7 & $1.34 \mathrm{E}-07$ \\
\hline $\mathrm{P}\{$ magu $\} 102$ & - & M & 38 & 34.6 & 16.4 & & & \\
\hline $\mathrm{P}\{$ magu $\} 102$ & + & $\mathrm{F}$ & 48 & 45.3 & 16.3 & 9.1 & 13.0 & $4.29 \mathrm{E}-07$ \\
\hline $\mathrm{P}\{$ magu $\} 102$ & - & $\mathrm{F}$ & 44 & 40.1 & 11.2 & & & \\
\hline $\mathrm{P}\{$ magu $\} 67-1$ & + & M & 50 & 44.8 & 18.4 & 31.6 & 29.5 & $7.16 \mathrm{E}-08$ \\
\hline $\mathrm{P}\{$ magu $\} 67-1$ & - & M & 38 & 34.6 & 17.3 & & & \\
\hline $\mathrm{P}\{$ magu $\} 67-1$ & + & $\mathrm{F}$ & 46 & 41.3 & 15.6 & 21.0 & 15.0 & $5.83 \mathrm{E}-07$ \\
\hline $\mathrm{P}\{$ magu $\} 67-1$ & - & $\mathrm{F}$ & 38 & 35.9 & 12.0 & & & \\
\hline $\mathrm{P}\{$ hebe $\} \mathrm{DX} 2$ & + & M & 50 & 48.4 & 12.4 & 19.0 & 17.8 & $2.46 \mathrm{E}-09$ \\
\hline $\mathrm{P}\{$ hebe $\} \mathrm{DX} 2$ & - & M & 42 & 41.1 & 10.0 & & & \\
\hline $\mathrm{P}\{$ hebe $\} \mathrm{DX} 2$ & + & $\mathrm{F}$ & 54 & 48.4 & 16.6 & 17.4 & 15.2 & $1.75 \mathrm{E}-05$ \\
\hline $\mathrm{P}\{$ hebe $\} \mathrm{DX} 2$ & - & $\mathrm{F}$ & 46 & 42 & 16.2 & & & \\
\hline $\mathrm{P}\{$ hebe $\} \mathrm{AX}$ & + & M & 46 & 45.8 & 12.0 & 9.5 & 13.6 & $2.45 \mathrm{E}-06$ \\
\hline $\mathrm{P}\{$ hebe $\} \mathrm{AX}$ & - & M & 42 & 40.3 & 9.8 & & & \\
\hline $\mathrm{P}\{$ hebe $\} \mathrm{AX}$ & + & $\mathrm{F}$ & 52 & 44.9 & 17.6 & 18.2 & 13.7 & 0.000207 \\
\hline$P\{$ hebe $\} A X$ & - & $\mathrm{F}$ & 44 & 39.5 & 16.5 & & & \\
\hline
\end{tabular}

A negative correlation between reproduction and life span is often observed when comparing different species and different individuals within a species, suggesting the existence of a "cost of reproduction" (Williams 1966; Partridge et al. 2005). One idea is that the cost of reproduction results from a trade-off, in which limiting metabolic resources are partitioned between reproduction and somatic maintenance pathways required for optimal longevity (Kirkwood 2005). One way to test for such a trade-off is to experimentally alter life span and ask what is the effect on reproduction. For example, inhibiting the IIS pathway in $C$. elegans (Johnson et al. 1993; Kenyon et al. 1993; Dillin 
Fig. 5 Fecundity assay with gene over-expression throughout adulthood. a-g Production of viable progeny. The indicated strains were crossed to rt-

TA(3)E2 ubiquitous driver and female progeny containing both constructs b-g and controls containing only the driver (a) were cultured as adults, in the absence of DOX (white bars), presence of DOX (black bars) and presence of DOX diluted 1:5 (dark gray bars) and DOX diluted 1:25 (light gray bars), as indicated. Drug treatment began on day one and continued throughout the adult life span. Fecundity (average pupal-stage progeny per female per day) is plotted for time period 1 (days 10-20) and time period 2 (days 30-40), as indicated. Error bars indicate standard deviation. The results for DOX-treated flies were compared to -DOX control using unpaired, two-sided $t$ tests, and statistically significant changes $(p<0.05)$ are indicated with asterisks. a Control w[1118]. b $\mathrm{P}\{\mathrm{PdL}\}$ magu. c $\mathrm{P}\{$ magu $\}$ 67-1. d $\mathrm{P}\{$ magu $\}$ 102. e $\mathrm{P}\{\mathrm{PdL}\}$ hebe. $\mathbf{f}$ $\mathrm{P}\{$ hebe $\}$ DX2. g P $\{$ hebe $\}$ AX. h Egg production for Control w1118, $\mathrm{P}\{$ magu $\} 102$ and $\mathrm{P}\{$ magu $\} 103$, in presence and absence of DOX, as indicated. $\mathbf{i}$ Fraction of eggs hatching for Control w[1118], P\{magu $\} 102$, and $\mathrm{P}\{\mathrm{magu}\} 103$, respectively, in presence and absence of DOX, as indicated. The data for $\mathbf{h}$ and $\mathbf{i}$ are from the same experiment
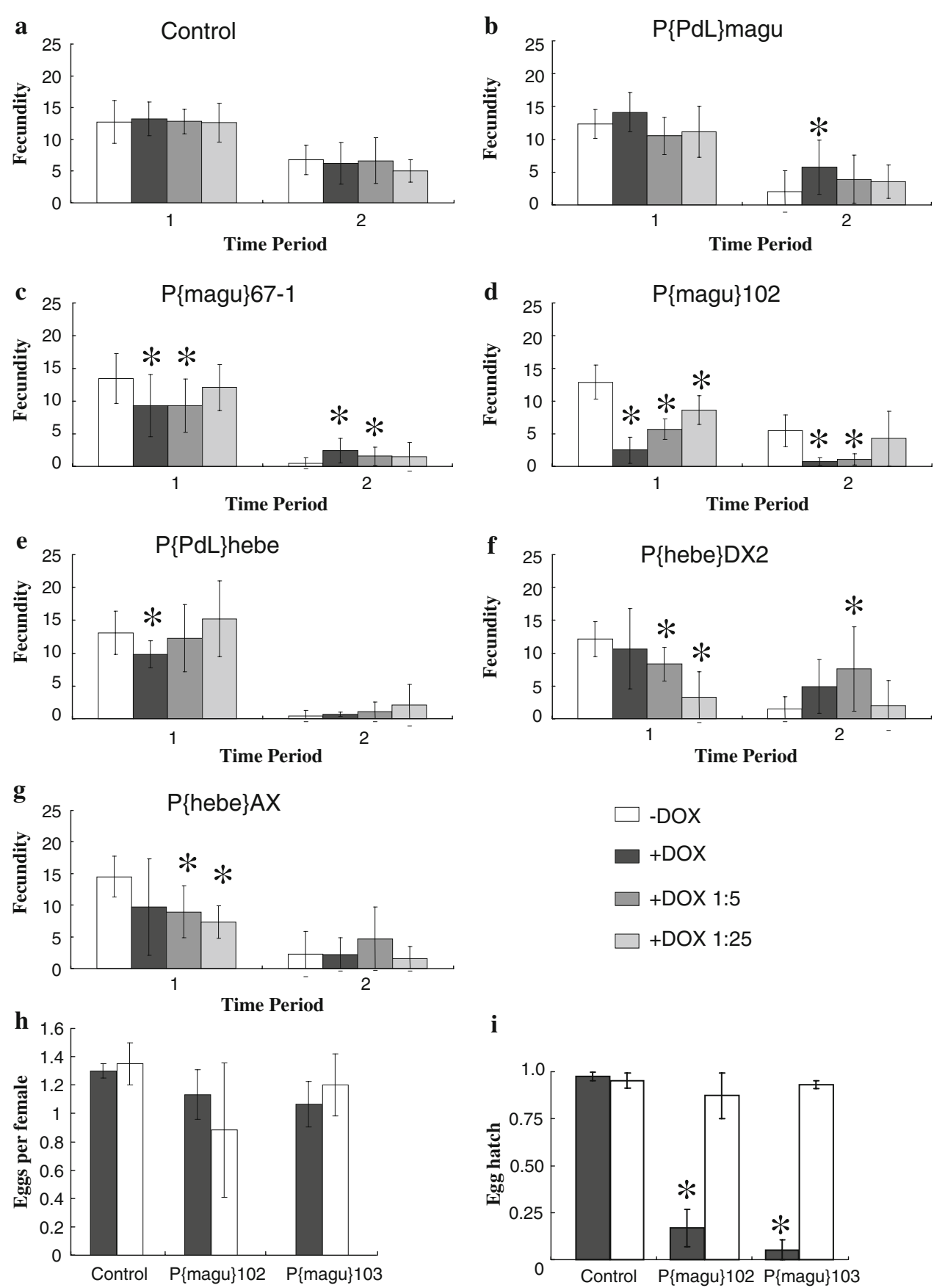

i

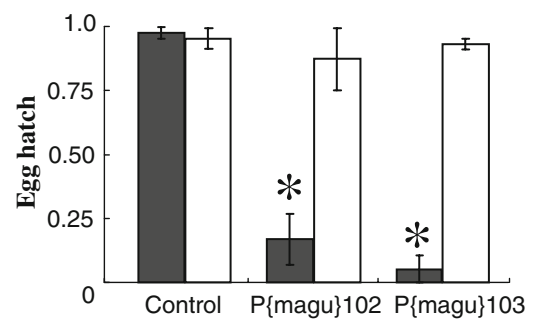

et al. 2002) or over-expressing dFOXO in adult Drosophila (Hwangbo et al. 2004) can increase life span without reducing reproduction, suggesting there is no obligatory cost of longevity. The other way to test for the trade-off is to experimentally manipulate reproduction and ask what is the effect on life span. Previous studies have involved experimentally decreasing reproduction (Sgro and Partridge 1999; Mair et al. 2004). However, experimental designs involving reduced reproduction provide limited inference, because reducing reproduction might not necessarily result in resources being redirected towards somatic maintenance in a usable way; reproduction might be decreased for a novel or pathological reason not related to processes that normally limit life span (Partridge et al. 2005). In contrast, the strategy employed in the present study works in the opposite direction: here $\mathrm{P}\{\mathrm{PdL}\}$ magu over-expression throughout adulthood, as well as magu and hebe overexpression starting at late ages, could increase female reproduction with no detectable cost to life span, in fact life span was also increased. These results provide strong additional arguments against the existence of an obligatory trade-off between reproduction and life span (Partridge 
Fig. 6 Fecundity and life span with gene over-expression initiated at age 40 days. The indicated strains were crossed to $\operatorname{rtTA}(3) \mathrm{E} 2$ ubiquitous driver and female progeny containing both constructs $(\mathbf{c}-\mathbf{i}, \mathbf{k}, \mathbf{l})$ and controls containing only the driver $(\mathbf{a}, \mathbf{b}$, j) were cultured as adults in the absence of DOX for 39 days. From day 40 onwards the flies were cultured in the absence of DOX (white bars), presence of DOX (black bars), presence of DOX diluted 1:5 (dark gray bars), and presence of DOX diluted 1:25 (light gray bars), as indicated. Fecundity (average pupal-stage progeny per female per day) is plotted for time period 1 (days 35-39) and time period 2 (days 45-49), as indicated. Error bars indicate standard deviation. The results for DOXtreated flies were compared to -DOX control using unpaired, two-sided $t$ tests, and statistically significant changes $(p<0.05)$ are indicated with asterisks. a Control Or-R. b Control $\mathrm{W}$ [1118]. c P $\{\mathrm{PdL}\}$ magu. d $\mathrm{P}\{$ magu $\} 102$. e $\mathrm{P}\{$ magu $\} 103$. f $\mathrm{P}\{$ magu $\}$ 67-1. g P $\{\mathrm{PdL}\}$ hebe. $\mathbf{h}$ $\mathrm{P}\{$ hebe $\} \mathrm{DX}$ 2. i P hebe $\}$ AX. (jl) Survival data for flies cultured in the presence (white diamonds) or absence (black squares) of DOX from day 40 onwards. The percent change in median life span is presented, along with $p$ value for log-rank tests. $\mathbf{j}$ Control (Or-R) females. $\mathbf{k}$ $\mathrm{P}\{$ PdL $\}$ magu females. I $\mathrm{P}\{\mathrm{PdL}\}$ hebe females
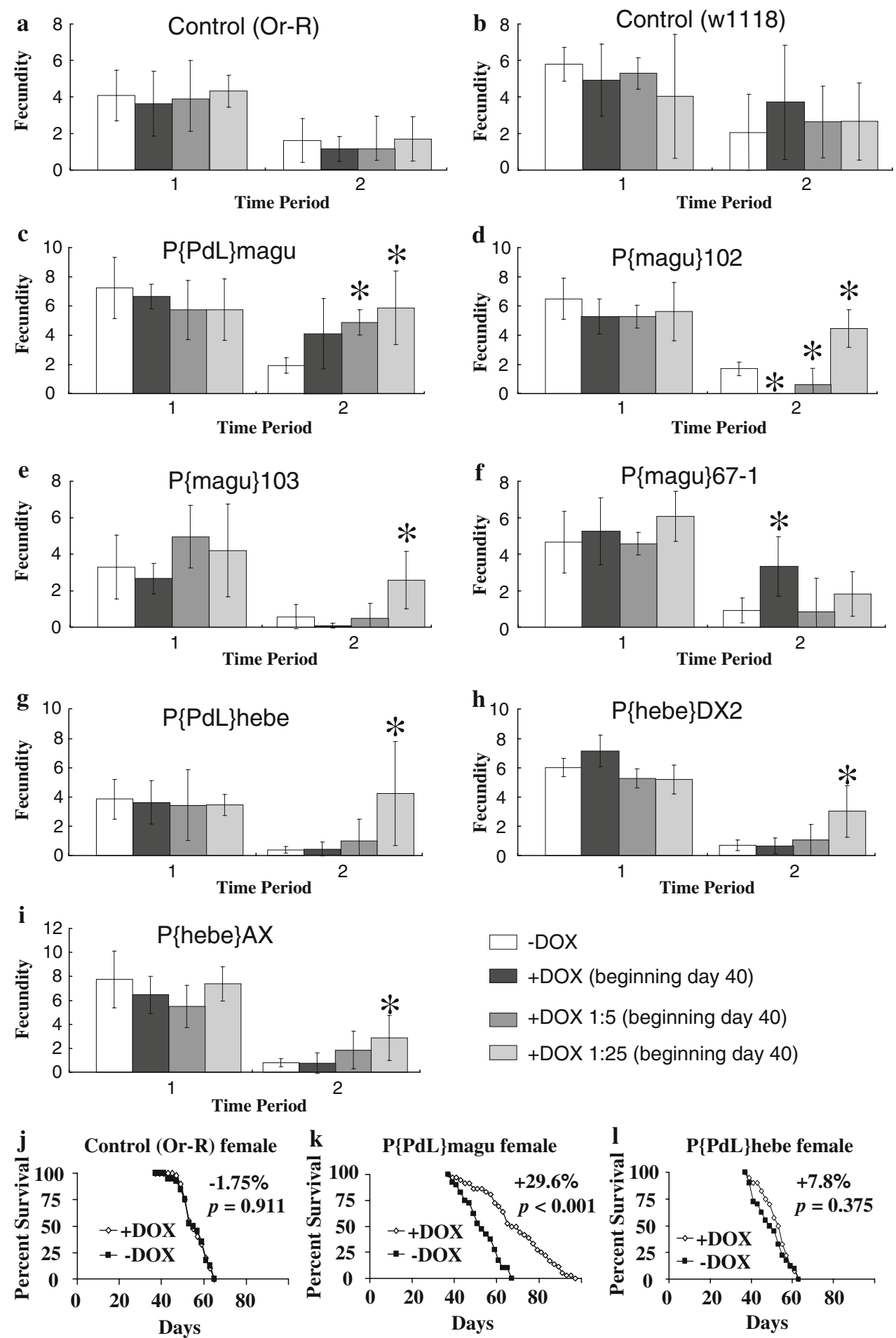

et al. 2005), and support the idea that aging-related mortality and fecundity decline may have a common underlying mechanism.

The magu gene sequence is most related to a human gene that stimulates angiogenesis, called SMOC2 (secreted modular calcium-binding protein 2) (Vannahme et al. 2003; Rocnik et al. 2006), including conserved EF-hand calciumbinding domains and a thyroglobulin type-1 repeat signa- ture (Fig. 2). Angiogenesis is impaired during aging in humans and other organisms, and this decline may be related to senescence of the vascular endothelial cells, which must continually divide to maintain existing vessels and support new vessel growth (Reed and Edelberg 2004). SMOC2 is located in the extracellular matrix and enhances the stimulatory effects of growth factors on mammalian cell proliferation. One hypothesis is that in flies magu could act 
through a similar mechanism, and favor late-age fecundity by stimulating stem cell division in the gonads. In a recent study the Drosophila genome was screened for genes that are preferentially expressed in the stem-cell region of the testes, and the most enriched gene identified was indeed magu (CG2264) (Terry et al. 2006). If Magu protein is in fact extracellular, as suggested by its sequence and similarity to mammalian SMOC2, this would place Magu in an appropriate location to function as part of the stem cell niche. For hebe, sequence homology searches revealed that related genes of unknown function exist in Drosophila pseudoobscura (GA14053) and Drosophila simulans (CG1623), however, no additional hebe-related genes could be found in other Drosophila species or in any other genus. Moreover, no conserved protein motifs or possible functions could be identified for hebe. The one report of a mutant phenotype for hebe is for a $\mathrm{P}$ element insertion in the gene associated with decreased male aggression (Edwards et al. 2006).

It will be of interest in the future to determine how magu over-expression might be acting to increase life span. The preferential expression of magu in the gonad stem cell regions is consistent with its effects on fecundity; however, the gonad stem cells do not appear to be the major determinant of animal longevity (Barnes et al. 2006; Flatt et al. 2008). Both the gut (Micchelli and Perrimon 2006; Ohlstein and Spradling 2006; Choi et al. 2008) and the malpighian tubule (analogous to mammalian kidney) (Singh et al. 2007) are maintained by stem cell division in the adult fly, and the possible role of these stem cell populations in life span is unknown. Northern analysis revealed that magu is expressed in other tissues of the fly (Fig. 3e), and a previous genomewide micro-array analysis of RNA levels in adult Drosophila tissues indicated that, in addition to ovary and nervous tissue, there was an enrichment for magu (CG2264) expression in the gut and malpighian tubule (Chintapalli et al. 2007), consistent with a correlation with stem cell locations.

It is notable that over-expression of magu and hebe preferentially in adult motor-neuron tissue was sufficient to produce increased life span. A small number of interventions have been shown to increase life span in Drosophila and other model organisms. These interventions include reduced insulin/IGF1-like signaling (IIS) (Clancy et al. 2001; Tatar et al. 2001; Kenyon 2005; Selman et al. 2008), activation of the IIS target transcription factor FOXO (Giannakou et al. 2004; Hwangbo et al. 2004), dietary restriction (DR) (Piper and Partridge 2007), reduced expression of mitochondrial genes during development (Dillin et al. 2002; Wolff and Dillin 2006), and altered redox homeostasis such as by over-expression of enzymes including SOD (Parkes et al. 1998; Sun and Tower 1999; Sun et al. 2002, 2004; Curtis et al. 2007; Hu et al. 2007). Interestingly, similar to magu and hebe, over-expression of
$\mathrm{Cu} / \mathrm{ZnSOD}$ preferentially in adult motor-neuron tissue is sufficient to extend life span (Parkes et al. 1998), with a preferential effect in females (Spencer et al. 2003). Future experiments will include further assay of tissue-specificity of effects of magu and hebe over-expression, for example by targeting over-expression to specific stem cell populations using the tissue-specific, DOX-regulated system (Ford et al. 2007). In addition it will be important to test whether the mechanism for life span increase might be related to one of the known pathways affecting life span.

Acknowledgments This work was supported by a Sr. Scholar Award to JT from the Ellison Medical Foundation, and a grant from the Department of Health and Human Services to JT (AG11833).

Open Access This article is distributed under the terms of the Creative Commons Attribution Noncommercial License which permits any noncommercial use, distribution, and reproduction in any medium, provided the original author(s) and source are credited.

\section{References}

Allikian MJ, Deckert-Cruz D, Rose MR, Landis GN, Tower J (2002) Doxycycline-induced expression of sense and inverted-repeat constructs modulates phosphogluconate mutase (Pgm) gene expression in adult Drosophila melanogaster. Genome Biol 3(5):research0021

Barnes AI, Boone JM, Jacobson J, Partridge L, Chapman T (2006) No extension of lifespan by ablation of germ line in Drosophila. Proc Biol Sci 273(1589):939-947

Bieschke ET, Wheeler JC, Tower J (1998) Doxycycline-induced transgene expression during Drosophila development and aging. Mol Gen Genet 258(6):571-579

Boyle M, Wong C, Rocha M, Jones DL (2007) Decline in self-renewal factors contributes to aging of the stem cell niche in the Drosophila testis. Cell Stem Cell 1(4):470-478

Chintapalli VR, Wang J, Dow JA (2007) Using FlyAtlas to identify better Drosophila melanogaster models of human disease. Nat Genet 39(6):715-720

Choi NH, Kim JG, Yang DJ, Kim YS, Yoo MA (2008) Age-related changes in Drosophila midgut are associated with PVF2, a PDGF/VEGF-like growth factor. Aging Cell 7(3):318-334

Clancy DJ, Gems D, Harshman LG, Oldham S, Stocker H, Hafen E, Leevers SJ, Partridge L (2001) Extension of life-span by loss of CHICO, a Drosophila insulin receptor substrate protein. Science 292:104-106

Curtis C, Landis GN, Folk D, Wehr NB, Hoe N, Waskar M, Abdueva D, Skvortsov D, Ford D, Luu A, Badrinath A, Levine RL, Bradley TJ, Tavare S, Tower J (2007) Transcriptional profiling of MnSOD-mediated lifespan extension in Drosophila reveals a species-general network of aging and metabolic genes. Genome Biol 8(12):R262

Dillin A, Hsu AL, Arantes-Oliveira N, Lehrer-Graiwer J, Hsin H, Fraser AG, Kamath RS, Ahringer J, Kenyon C (2002) Rates of behavior and aging specified by mitochondrial function during development. Science 298(5602):2398-2401

Drummond-Barbosa D, Spradling AC (2001) Stem cells and their progeny respond to nutritional changes during Drosophila oogenesis. Dev Biol 231(1):265-278

Edwards AC, Rollmann SM, Morgan TJ, Mackay TF (2006) Quantitative genomics of aggressive behavior in Drosophila melanogaster. PLoS Genet 2(9):e154 
Flatt T, Kawecki TJ (2007) Juvenile hormone as a regulator of the trade-off between reproduction and life span in Drosophila melanogaster. Evolution 61(8):1980-1991

Flatt T, Min KJ, D'Alterio C, Villa-Cuesta E, Cumbers J, Lehmann R, Jones DL, Tatar M (2008) Drosophila germ-line modulation of insulin signaling and lifespan. Proc Natl Acad Sci USA 105(17):6368-6373

Ford D, Hoe N, Landis GN, Tozer K, Luu A, Bhole D, Badrinath A, Tower J (2007) Alteration of Drosophila life span using conditional, tissue-specific expression of transgenes triggered by doxycycline or RU486/Mifepristone. Exp Gerontol 42(6):483-497

Fuller MT, Spradling AC (2007) Male and female Drosophila germline stem cells: two versions of immortality. Science 316(5823):402-404

Giannakou ME, Goss M, Junger MA, Hafen E, Leevers SJ, Partridge L (2004) Long-lived Drosophila with overexpressed dFOXO in adult fat body. Science 305(5682):361

Giannakou ME, Goss M, Partridge L (2008) Role of dFOXO in lifespan extension by dietary restriction in Drosophila melanogaster: not required, but its activity modulates the response. Aging Cell 7(2):187-198

Hekimi S (2006) How genetic analysis tests theories of animal aging. Nat Genet 38(9):985-991

Howlader G, Sharma VK (2006) Circadian regulation of egg-laying behavior in fruit flies Drosophila melanogaster. J Insect Physiol 52(8):779-785

Hsu HJ, LaFever L, Drummond-Barbosa D (2008) Diet controls normal and tumorous germline stem cells via insulin-dependent and -independent mechanisms in Drosophila. Dev Biol 313(2):700_ 712

Hu D, Cao P, Thiels E, Chu CT, Wu GY, Oury TD, Klann E (2007) Hippocampal long-term potentiation, memory, and longevity in mice that overexpress mitochondrial superoxide dismutase. Neurobiol Learn Mem 87(3):372-384

Hwangbo DS, Gersham B, Tu MP, Palmer M, Tatar M (2004) Drosophila $\mathrm{dFOXO}$ controls lifespan and regulates insulin signalling in brain and fat body. Nature 429(6991):562-566

Johnson TE, Tedesco PM, Lithgow GJ (1993) Comparing mutants, selective breeding, and transgenics in the dissection of aging processes of Caenorhabditis elegans. Genetica 91(1-3):65-77

Kenyon C (2005) The plasticity of aging: insights from long-lived mutants. Cell 120(4):449-460

Kenyon C, Chang J, Gensch E, Rudner A, Tabtiang R (1993) A C. elegans mutant that lives twice as long as wild type. Nature 366(6454):461-464

Khokhar A, Chen N, Yuan J, Li Y, Landis GN, Beaulieu G, Kaur H, Tower J (2008) Conditional switches for extracellular matrix patterning in Drosophila melanogaster. Genetics 178(3):1283-1293

Kirkwood TB (2005) Understanding the odd science of aging. Cell 120(4):437-447

LaFever L, Drummond-Barbosa D (2005) Direct control of germline stem cell division and cyst growth by neural insulin in Drosophila. Science 309(5737):1071-1073

Landis G, Bhole D, Lu L, Tower J (2001) High-frequency generation of conditional mutations affecting Drosophila melanogaster development and life span. Genetics 158(3):1167-1176

Landis GN, Bhole D, Tower J (2003) A search for doxycycline-dependent mutations that increase Drosophila melanogaster life span identifies the VhaSFD, Sugar baby, filamin, fwd and Cctl genes. Genome Biol 4(2):R8

Mair W, Sgro CM, Johnson AP, Chapman T, Partridge L (2004) Lifespan extension by dietary restriction in female Drosophila melanogaster is not caused by a reduction in vitellogenesis or ovarian activity. Exp Gerontol 39(7):1011-1019

Micchelli CA, Perrimon N (2006) Evidence that stem cells reside in the adult Drosophila midgut epithelium. Nature 439(7075):475-479
Min KJ, Yamamoto R, Buch S, Pankratz M, Tatar M (2008) Drosophila lifespan control by dietary restriction independent of insulinlike signaling. Aging Cell 7(2):199-206

Morrison SJ, Spradling AC (2008) Stem cells and niches: mechanisms that promote stem cell maintenance throughout life. Cell 132(4):598-611

Ohlstein B, Spradling A (2006) The adult Drosophila posterior midgut is maintained by pluripotent stem cells. Nature 439(7075):470 474

Pan L, Chen S, Weng C, Call G, Zhu D, Tang H, Zhang N, Xie T (2007) Stem cell aging is controlled both intrinsically and extrinsically in the Drosophila ovary. Cell Stem Cell 1(4):458-469

Parkes TL, Elia AJ, Dickson D, Hilliker AJ, Phillips JP, Boulianne GL (1998) Extension of Drosophila lifespan by overexpression of human SOD1 in motorneurons. Nature Genet 19:171-174

Partridge L, Tower J (2008) Yeast, a feast: the fruit fly Drosophila as a model organism for research into aging. In: Guarente LP, Partridge L, Wallace DC (eds) Molecular biology of aging. Cold Spring Harbor Laboratory Press, Cold Spring Harbor, pp 267-308

Partridge L, Gems D, Withers DJ (2005) Sex and death: what is the connection? Cell 120(4):461-472

Patton JS, Gomes XV, Geyer PK (1992) Position-independent germline transformation in Drosophila using a cuticle pigmentation gene as a selectable marker. Nucleic Acids Res 20:5859-5860

Piper MD, Partridge L (2007) Dietary restriction in Drosophila: delayed aging or experimental artefact? PLoS Genet 3(4):e57

Reed MJ, Edelberg JM (2004) Impaired angiogenesis in the aged. Sci Aging Knowledge Environ 2004(7):pe7

Ren C, Webster P, Finkel SE, Tower J (2007) Increased internal and external bacterial load during Drosophila aging without life-span trade-off. Cell Metab 6(2):144-152

Rocnik EF, Liu P, Sato K, Walsh K, Vaziri C (2006) The novel SPARC family member SMOC-2 potentiates angiogenic growth factor activity. J Biol Chem 281(32):22855-22864

Rubin GM, Spradling AC (1982) Genetic transformation of Drosophila with transposable element vectors. Science 218:348-353

Selman C, Lingard S, Choudhury AI, Batterham RL, Claret M, Clements M, Ramadani F, Okkenhaug K, Schuster E, Blanc E, Piper MD, Al-Qassab H, Speakman JR, Carmignac D, Robinson IC, Thornton JM, Gems D, Partridge L, Withers DJ (2008) Evidence for lifespan extension and delayed age-related biomarkers in insulin receptor substrate 1 null mice. Faseb J 22(3):807-818

Sgro CM, Partridge L (1999) A delayed wave of death from reproduction in Drosophila. Science 286(5449):2521-2524

Singh SR, Liu W, Hou SX (2007) The adult Drosophila malpighian tubules are maintained by multipotent stem cells. Cell Stem Cell 1:191-203

Spencer CC, Howell CE, Wright AR, Promislow DE (2003) Testing an 'aging gene' in long-lived drosophila strains: increased longevity depends on sex and genetic background. Aging Cell 2(2):123130

Stebbins MJ, Urlinger S, Byrne G, Bello B, Hillen W, Yin JC (2001) Tetracycline-inducible systems for Drosophila. Proc Natl Acad Sci USA 98(19):10775-10780

Sun J, Tower J (1999) FLP recombinase-mediated induction of $\mathrm{Cu} / \mathrm{Zn}$ superoxide dismutase transgene expression can extend the life span of adult Drosophila melanogaster flies. Mol Cell Biol 19(1):216-228

Sun J, Folk D, Bradley TJ, Tower J (2002) Induced overexpression of mitochondrial Mn-superoxide dismutase extends the life span of adult Drosophila melanogaster. Genetics 161(2):661-672

Sun J, Molitor J, Tower J (2004) Effects of simultaneous over-expression of $\mathrm{Cu} / \mathrm{ZnSOD}$ and MnSOD on Drosophila melanogaster life span. Mech Ageing Dev 125(5):341-349

Tatar M, Kopelman A, Epstein D, Tu MP, Yin CM, Garofalo RS (2001) A mutant Drosophila insulin receptor homolog that 
extends life-span and impairs neuroendocrine function. Science 292(5514):107-110

Terry NA, Tulina N, Matunis E, DiNardo S (2006) Novel regulators revealed by profiling Drosophila testis stem cells within their niche. Dev Biol 294(1):246-257

Toivonen JM, Partridge L (2008) Endocrine regulation of ageing and reproduction in Drosophila. Mol Cell Endocrinol. doi:10.1016/ j.mce.2008.07.005

Tower J (2000) Transgenic methods for increasing Drosophila life span. Mech Ageing Dev 118(1-2):1-14

Vannahme C, Gosling S, Paulsson M, Maurer P, Hartmann U (2003) Characterization of SMOC-2, a modular extracellular calciumbinding protein. Biochem J 373(Pt 3):805-814

Wallenfang MR, Nayak R, DiNardo S (2006) Dynamics of the male germline stem cell population during aging of Drosophila melanogaster. Aging Cell 5(4):297-304
Waskar M, Li Y, Tower J (2005) Stem Cell Aging in the Drosophila Ovary. Age 27:201-212

Williams GC (1966) Natural selection, the costs of reproduction, and a refinement of Lack's principle. Amer Natur 100:687-690

Wolff S, Dillin A (2006) The trifecta of aging in Caenorhabditis elegans. Exp Gerontol 41(10):894-903

Yamawaki TM, Arantes-Oliveira N, Berman JR, Zhang P, Kenyon C (2008) Distinct activities of the germline and somatic reproductive tissues in the regulation of Caenorhabditis elegans' longevity. Genetics 178(1):513-526

Zhao R, Xuan Y, Li X, Xi R (2008) Age-related changes of germline stem cell activity, niche signaling activity and egg production in Drosophila. Aging Cell 7(3):344-354 